\title{
CHANGES IN PREVENTION AND OUTBREAK MANAGEMENT OF LEgIONNAIRES' DISEASE IN THE NeTHERLANDS BETWEEN TWO LARGE OUTBREAKS IN 1999 AND 2006
}

\section{G J Sonder (gsonder@ggd.amsterdam.nl)1, J A van den Hoek ${ }^{1}$, L P Bovée ${ }^{1}$, F E Aanhane ${ }^{1}$, J Worp ${ }^{1}$, M Du Ry van Beest Holle ${ }^{2}$, $\mathrm{J}$ E van Steenbergen ${ }^{2}$, J W den Boer ${ }^{3}$, E P Ijzerman ${ }^{3}$, R A Coutinho ${ }^{2}$}

1. Gemeentelijke Gezondheidsdienst (GGD) Amsterdam (Public Health Service Amsterdam) Department of Infectious Diseases, Amsterdam, the Netherlands

2. Centrum Infectieziektebestrijding (Centre for Infectious Disease Control, CIb), Rijksinstituut voor Volksgezondheid en Milieu (National Institute for Public Health and the Environment, RIVM), Preparedness and Response Unit, Bilthoven, the Netherlands 3. Regional Laboratory of Public Health Haarlem, Haarlem, the Netherlands

\begin{abstract}
We describe an outbreak of Legionnaires' disease in 2006 in Amsterdam, the Netherlands. Comparisons with the outbreak that took place in 1999 are made to evaluate changes in legionella prevention and outbreak management. The 2006 outbreak was caused by a wet cooling tower. Thirty-one patients were reported. The outbreak was detected two days after the first patient was admitted to hospital, and the source was eliminated five days later. The 1999 outbreak was caused by a whirlpool at a flower show, and 188 patients were reported. This outbreak was detected 14 days after the first patient was admitted to hospital, and two days later the source was traced. Since 1999, the awareness of legionellosis among physicians, the availability of a urinary antigen tests and more efficient early warning and communication systems improved the efficiency of legionellosis outbreak management. For prevention, extensive legislation with clear responsibilities has been put in place. For wet cooling towers, however, legislation regarding responsibility and supervision of maintenance needs to be improved.
\end{abstract}

\section{Introduction}

Legionnaires' disease (LD) is an acute pneumonia caused by infection with bacteria of the genus Legionella. Inhalation of aerosolized water containing the bacteria is the primary mode of acquisition. Although cases of LD are often sporadic, large outbreaks can be caused by communal sources, such as 'hot tubs' or 'spa pools' [1,2] and hospital or hotel showers [3,4]. Wet cooling towers can emit contaminated aerosols, with dispersal over long distances, sometimes causing major outbreaks [5-15].

In the Netherlands, the first large LD outbreak occurred in 1999; it affected 188 patients of whom 23 died. This epidemic was caused by aerosol transmission from a display whirlpool at a flower show, and was not recognized as an LD outbreak until 14 days after the first patient was diagnosed with pneumonia of unknown origin. The source was identified within a week after the epidemic was detected as an LD outbreak; 10 days after the show had ended, when already 71 patients had been admitted to various hospitals throughout the country. The 1999 outbreak was evaluated extensively [16] and this has led to changes in prevention policies, legislation and outbreak management strategies.
Here we describe the second large outbreak of LD in the Netherlands in 2006, and evaluate the effectiveness of changes in legislation, prevention management and outbreak management implemented after the first large outbreaks in 1999.

\section{Methods}

In the Netherlands, LD has been a reportable disease since 1987. Every diagnosed case has to be reported to the local Public Health Service (PHS), and is registered nationally by the Centre for Infectious Disease Control (Clb). Since 2002, the local PHSs report to $\mathrm{Clb}$ by the internet.

A confirmed LD case is a patient with pneumonia, confirmed by a positive laboratory test (urinary antigen test, positive culture, positive polymerase chain reaction (PCR), positive IgM antibody or a significant increase in IgG antibody ELISA test). After a case of LD has been reported to the PHS, patient information is gathered including demographics, diagnosis, underlying disease, domestic risk factors, risk factors at work, travel, and leisure activities in the 21 days before onset of disease, using a standardised questionnaire [17].

Any unusual number of reported cases in time or place will lead to an outbreak investigation as to a common source. In case an outbreak is suspected, depending on the suspected source, active case-finding is initiated by the PHS in order to detect and eliminate the source as soon as possible. Depending on the magnitude of the outbreak, active case-finding comprises alerting general practitioners and hospitals in the PHS area, other PHS branches and international early warning systems. Since 2002, in case an outbreak is suspected that is not confined to one PHS area, the Clb informs the other PHSs and other physicians by email service, which makes it possible to notify them instantly. The public can be warned by local or national press and television.

To strengthen local efforts to identify sources, a specialized team from the Regional Public Health Laboratory of Haarlem has offered sampling services to all public health services in the Netherlands since 2002, and serves as a reference laboratory where both human 
and environmental strains are genotyped. The laboratory keeps a national register of sampled potential sources.

For the 2006 outbreak investigation, the following case definition was made: confirmed cases were patients with clinical signs of pneumonia, with fever $>380 \mathrm{C}$, cough and shortness of breath, who had been to the eastern part of Amsterdam (with zip codes 1011 and 1018) between 8 June and 11 July and with a confirmed laboratory test (positive urinary antigen test; positive culture; fourfold increase in antibody titer or seroconversion in a paired sample).

All hospital laboratories were asked to send available cultures to the reference laboratory in Haarlem for genotyping, where Amplified Fragment Length Polymorphism (AFLP) was used for DNA fingerprinting.

Although wet cooling towers are a common source of LD outbreaks, in the Netherlands registration of these towers is not addressed in the law (Table 1). As soon as a cooling tower was suspected as the source of the outbreak, for tracing of this source wind directions were used as published by the Dutch National Meteorological Institute KNMI. [www.knmi.nl/klimatologie/ daggegevens/index.cgi] All environmental samples were obtained by the department of Infectious Diseases of the PHS Amsterdam in cooperation with the Public Health Laboratory Haarlem

\section{Results}

\section{Source tracing}

On Thursday 6 July 2006, three cases of LD were reported to the PHS in Amsterdam, all diagnosed on the same day by a urine test indicating type I infection. On Friday 7 July, the second day when five cases were reported, the PHS Amsterdam continued the source tracing and started active case-finding by emailing all general practitioners who were on call that weekend ( 8 and 9 July). All six Amsterdam hospitals were called to alert and inform the microbiologists about the outbreak. Also, all other PHS branches in the Netherlands were notified by $\mathrm{Clb}$ email service and requested to report any unusual number of LD cases or cases that could be related to a recent visit to Amsterdam. During the weekend, nine additional cases were reported. Extensive interviewing did not suggest a common source for these infections. None of the patients had traveled recently. The majority of patients were living in the city centre, in an area about 500 meters east of the central railway station with zip codes 1011 or 1018 , which is an area with a 2,5-3 km in diameter. Most of these patients reported onset of disease on the first of July (Figure 1).

On 8 July, the first sample was taken from a possible source, a newly installed display fountain, because most patients reported by then were living in the fountain area. This fountain was immediately closed.

Because it was possible that the outbreak was not confined to Amsterdam, on Monday 10 July, a national outbreak team was established, with participants from the PHS Amsterdam, the $\mathrm{Clb}$ and the Public Health Laboratory of Haarlem. The Clb started enhanced national active case-finding by contacting all infectious disease control physicians at PHS facilities in the regions surrounding Amsterdam. They were asked to telephone all hospitals in their region and ask if there had been any LD patients admitted. Also on 10 July, all general practitioners, microbiologists and infectiologists in Amsterdam were alerted by post. In order to alert as many people in the Netherlands as possible, a press release was issued on Monday announcing the unusual number of LD patients in Amsterdam.

T A B L E

Legislation and supervision of preventive legionella source cleansing in the Netherlands, 2007

\begin{tabular}{|c|c|c|c|c|}
\hline Laws & & Supervisor & Location & Object/source \\
\hline \multirow[t]{2}{*}{ Law on drinking water } & Chapter IIIC & Inspectorate of VROM & $\begin{array}{l}\text { Hospitals, housing, camping } \\
\text { sites, asylum seekers' } \\
\text { centers, yacht-basins }\end{array}$ & Drinking water installations \\
\hline & $\begin{array}{l}\text { Chapter IIIC articles } 17 j, 170 \text {, } \\
17 p, 17 q\end{array}$ & Inspectorate of VROM & $\begin{array}{l}\text { Drinking water companies } \\
\text { (waterworks) }\end{array}$ & Drinking water delivery \\
\hline \multirow[t]{5}{*}{$\begin{array}{l}\text { Law on occupational health } \\
\text { and safety }\end{array}$} & $\begin{array}{l}\text { Policy regulation* document } \\
4.87-1\end{array}$ & $\begin{array}{l}\text { Labor Inspectorate } \\
\text { SZW }\end{array}$ & $\begin{array}{l}\text { Locations in companies with } \\
\text { exposure risk for employees }\end{array}$ & \multirow{2}{*}{$\begin{array}{l}\text { Cooling towers } \\
\text { Humidifiers } \\
\text { Industrial water } \\
\text { installations }\end{array}$} \\
\hline & & $\begin{array}{l}\text { Food and Consumer product } \\
\text { safety authority }\end{array}$ & $\begin{array}{l}\text { Locations in companies with } \\
\text { public exposure risk }\end{array}$ & \\
\hline & & Labor Inspectorate & Inland shipping & \multirow{3}{*}{$\begin{array}{l}\text { Drinking water installations } \\
\text { Humidifiers } \\
\text { Industrial water } \\
\text { installations }\end{array}$} \\
\hline & & $\begin{array}{l}\text { Inspectorate of Transport, } \\
\text { Public Works and Water } \\
\text { Management }\end{array}$ & Ocean shipping & \\
\hline & & $\begin{array}{l}\text { Inspectorate of Transport, } \\
\text { Public Works and Water } \\
\text { Management }\end{array}$ & Airplanes & \\
\hline $\begin{array}{l}\text { Law on hygiene and safety } \\
\text { public baths and swimming } \\
\text { pools }\end{array}$ & Articles 2a-2d & Provinces & $\begin{array}{l}\text { Public baths and swimming } \\
\text { pools }\end{array}$ & Swimming and bathing water \\
\hline $\begin{array}{l}\text { Law on collective prevention } \\
\text { in public health }\end{array}$ & & Municipalities & Large-scale events & All atomizing installations \\
\hline
\end{tabular}

VROM: Ministry of Housing, Spatial planning and the Environment

SZW: Ministry of Social Affairs and Employment

* A policy regulation is not a law but a guideline; it describes best practice but does not have to be obeyed.

** Atomizing installations outside companies (such as fountains on squares or in shopping malls) are not part of this, or any other law. 
In the ten days preceding the outbreak, the wind appeared to be mainly west and north-west (Figure 1 ). Therefore, the team started to look for fountains and wet cooling towers north-west of the affected area. Subsequently a second display fountain in this area was sampled and immediately closed. Since registration of wet cooling towers is not mandatory, a register of these cooling towers was not available. However, in 2003, a list of wet cooling towers was made in Amsterdam for a study on the prevalence of legionellae, but had not since been updated. With the help of Google Earth, we looked for new, not registered cooling towers, and also inspected the area. As a result, every cooling tower in the outbreak area was inspected and sampled. At the end of the day on 10 July, we detected one (previously not listed) wet cooling tower on ground floor level, a few meters east of a construction site just east of the central station. This cooling tower was installed on 10 June and was visibly not well maintained. Samples were taken from the tower and as a precautionary measure the tower was closed as soon as possible in the early morning of Tuesday 11 July. The next day, the laboratory results showed positive culture and revealed a concentration of 5 million colony-forming units per liter. In a follow-up press release issued on the same day, it was announced that most patients affected lived in or had recently visited the area east of Amsterdam Central Station, and that a cooling tower in this area was the probable source of the outbreak.

\section{Active case-finding}

On 10 July, all public health physicians in the country were updated about the outbreak by $\mathrm{Clb}$ email service and asked to query all LD patients about visits to Amsterdam, including specific locations visited. In total, active case-finding yielded seven LD patients who lived outside Amsterdam but all of them worked in or very near the construction site adjacent to the questionable cooling tower. These findings confirmed our suspicion that it was the source of the outbreak.

Active case finding within the Occupational Health Services of the construction companies working near the cooling tower revealed that one construction worker had died on 6 July from pneumonia.
He fell ill on 4 July and refused admittance to hospital for further testing. A post-mortem lung specimen was tested and legionella bacteria could be detected by DNA isolation.

In July, many tourists visit Amsterdam. Because the LD source was so close to Amsterdam Central Station, the fear arose that international visitors could have been exposed, perhaps in large numbers. Therefore, on 12 July, the European Surveillance Scheme for Travel-Associated Legionnaires' Disease issued a community cluster alert to its participants [18] and a preliminary report was published in Eurosurveillance [19]. On 13 July, information on the outbreak appeared in ProMed [20]. No cases in tourists or visitors to Amsterdam were reported.

\section{Characteristics of patients}

In total, 31 patients with LD were reported in this outbreak: their characteristics are shown in Table 2. Seventy-four percent were men, and the case fatality rate was $10 \%$. Sixty-five percent reported possible risk factors associated with developing LD.

\section{Cultures and DNA fingerprinting}

From seven patients epidemiologically linked to the contaminated cooling tower, cultures were available for DNA fingerprinting, enabling comparison with the bacteria obtained from the cooling tower. All seven matched. In Figure 3, three of these seven samples are shown (patient 2, 3 and 4) in comparison to another patient not related to this outbreak (patient 1 ) and samples from the cooling tower (samples 5,6,7 and 8). At the same time, at a routine control, legionellae were found in another wet cooling tower in Amsterdam, five kilometers south-west of Central Station. However, the strain found in this tower (samples 9 and 10) was evidently different from the strain found in the outbreak patients.

\section{Discussion}

\section{Outbreak management}

The most important development since the 1999 outbreak is that urinary antigen tests have become widely available and physicians more aware of LD. The 1999 outbreak was not recognized as an

F I G U R E 1

Legionnaires' Disease (LD) patients in Amsterdam linked to a cooling tower, by date of onset of disease, June - July 2006 ( $n=31$ )

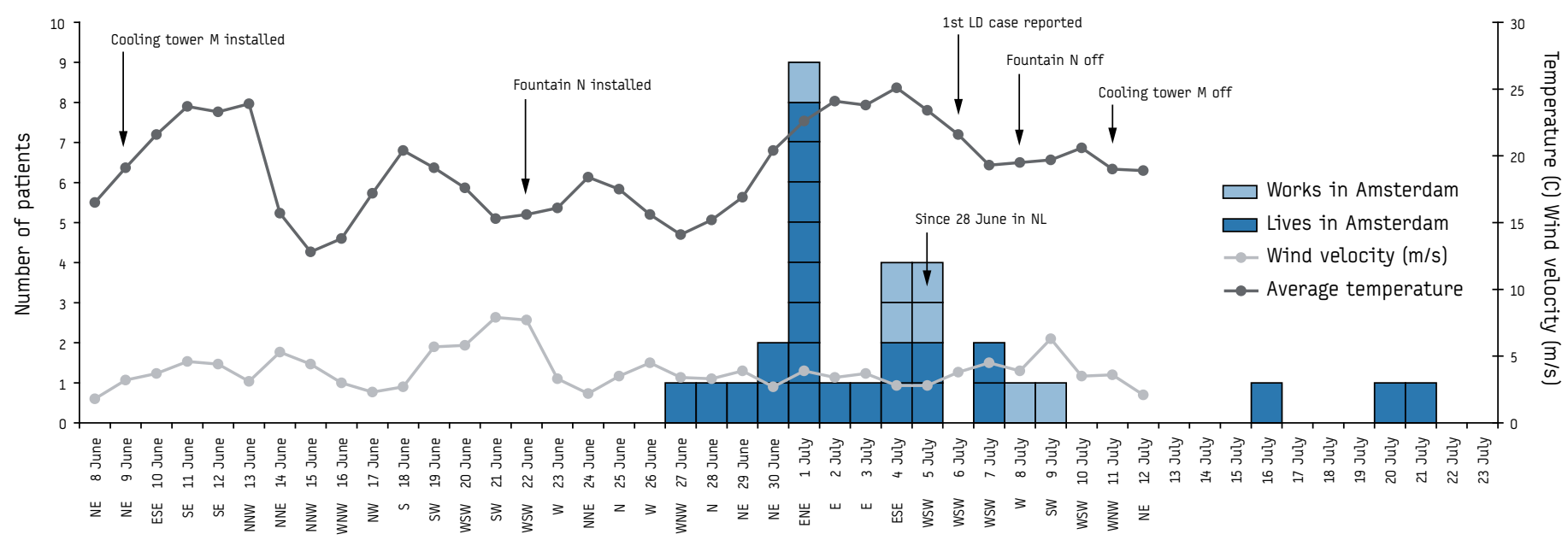


LD outbreak until 14 days after the first patient was hospitalized and diagnosed as a case of pneumonia of unknown origin. Hospital physicians were not aware that LD was a notifiable disease; they contacted the PHS because of the unusual number of pneumonia patients. In 2006, the first patient was diagnosed with LD within two days after hospital admission and reported to the PHS the same day the diagnosis was confirmed.

In the Amsterdam outbreak in which standardized questionnaires were used, the likelihood of a source outside a building (i.e. a cooling tower or a fountain) became clear after two days, by exclusion of communal sources. The actual source, a cooling tower, was located within four days after the first patient was diagnosed. In contrast, in 1999, a case control-study showed that it was likely that the source of the outbreak was situated at a flower show. Subsequent environmental risk assessment led to the most likely source, a

TA B L E 2

Characteristics of patients with Legionnaires' disease associated with cooling tower as most likely source of infection, Amsterdam, June - July $2006(\mathrm{n}=31)$

\begin{tabular}{|c|c|c|}
\hline Total number of patients & 31 & $100 \%$ \\
\hline \multicolumn{3}{|l|}{ Sex } \\
\hline Male & 23 & $74 \%$ \\
\hline Female & 8 & $26 \%$ \\
\hline \multicolumn{3}{|l|}{ Age } \\
\hline Average age (range) in years & $56(32-81)$ & \\
\hline \multicolumn{3}{|l|}{ Age distribution in years } \\
\hline $30-39$ & 3 & $10 \%$ \\
\hline 40-49 & 8 & $26 \%$ \\
\hline 50-59 & 7 & $23 \%$ \\
\hline 60-69 & 9 & $29 \%$ \\
\hline $70-79$ & 3 & $10 \%$ \\
\hline 80-89 & 1 & $3 \%$ \\
\hline \multicolumn{3}{|l|}{ Diagnosis } \\
\hline Urinary test & 31 & $100 \%$ \\
\hline Urinary test + culture & 7 & $23 \%$ \\
\hline \multicolumn{3}{|l|}{ History taken in acute stage } \\
\hline Patient & 17 & $55 \%$ \\
\hline Relative/proxy & 14 & $45 \%$ \\
\hline \multicolumn{3}{|l|}{ Deceased } \\
\hline Number of deaths, case fatality rate & 3 & $10 \%$ \\
\hline \multicolumn{3}{|l|}{ Associated factors } \\
\hline Diabetes type II & 5 & $16 \%$ \\
\hline Immune deficiency & 2 & $6 \%$ \\
\hline COPD & 3 & $10 \%$ \\
\hline Other lung disease & 1 & $3 \%$ \\
\hline Hypertension & 2 & $6 \%$ \\
\hline Smoker & 11 & $35 \%$ \\
\hline Alcoholism & 2 & $6 \%$ \\
\hline Any associated factor & 20 & $65 \%$ \\
\hline
\end{tabular}

whirlpool, and sampling revealed abundant legionella growth six weeks after the outbreak was recognized. [21]

Until 2002, national registration of reported LD cases was done by post from PHSs to $\mathrm{Clb}$, where cases were subsequently entered in a database. This procedure resulted in delays in the 'early warning system'. Since 2002, national registration is done by internet reporting, which is much faster. Especially outbreaks in different PHS districts can now be detected faster than in 1999. Also, communication from the $\mathrm{Clb}$ to $\mathrm{PHSs}$ has improved by the installation of a Clb email service in 2002. The service makes it possible to notify public health and other physicians instantly. In 1999, this was done by telephone and facsimile, which was much slower. Also, internationally, early warning systems have been put in place. $[28,20]$

The work of the reference laboratory has also proven successful; in the first two years of the project, the lab discovered 17 LD clusters, 12 of which would not have been identified in a timely manner without this outbreak detection program. [22] Because the

F I G U R E 2

The annual number of reported cases of Legionnaires' disease in The Netherlands, 1987-2006

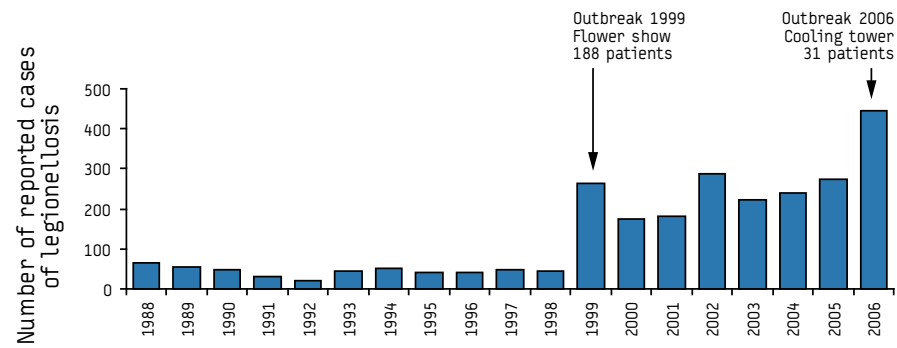

F I G U R E 3

Results of DNA fingerprinting of four Legionnaires' disease patients and two cooling towers in Amsterdam, 2006

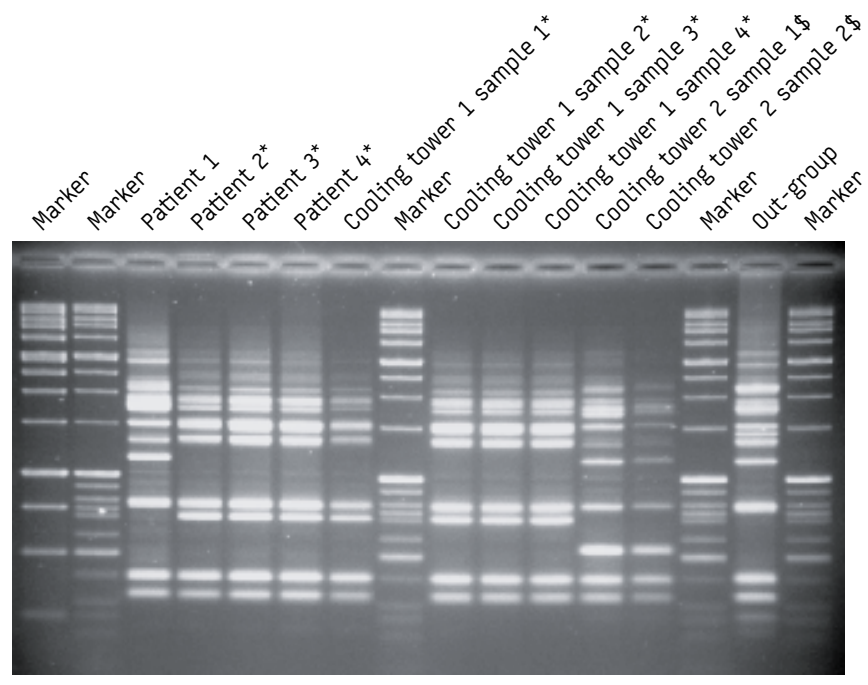

* Patients and cooling tower 1 match

$\$$ cooling tower 2 was located 5 kilometers south-west of cooling tower 1 
project was so successful, it was implemented in routine outbreak control and is coordinated by Clb since 2006. [23]

Because of their experience with sampling of possible legionella sources, in the 2006 outbreak the Regional Public Health Laboratory of Haarlem could take the first samples of suspected sources immediately after they were identified, starting on Saturday evening. Four days after the first patient was diagnosed, the actual source was sampled and one day later closed.

Increased awareness and availability of antigen tests are probably the reason why since the 1999 outbreak, the number of reported LD cases in the Netherlands has increased steadily (Figure 2). In 2006, the incidence of LD in the Netherlands was higher than in previous years. This increase cannot be explained only by the Amsterdam outbreak or increased awareness. The same trend was seen in the United Kingdom. [24] In both countries many sporadic cases spread all over the country were reported, which may be associated with certain weather conditions. In a recent study, warm and wet weather patterns, but not the hottest ones, were found to be associated with a higher incidence of LD in The Netherlands between 2003 and 2007 [25]

\section{Legionella prevention and legislation}

After the 1999 outbreak, the Dutch government launched a plan to combat Legionnaires' disease [26] which has resulted in the report 'Controlling Legionnaires' Disease', published by the Health Council in 2003 [27]. The report targets four areas in which the risk of infection could be reduced at acceptable cost: 1) Europeanwide agreement on guidelines (since about half of the patients are infected abroad); 2) rapid diagnosis and treatment; 3) modification of water fittings and implementation of management plans; and 4) stimulation of research to further rationalize prevention policies. The report states that some water atomizers (those used at large scale events, by residential properties, by small companies, and atomizers that are not connected to the main water system), and wet cooling towers used for comfort cooling need better maintenance.

New preventive legislation about control of legionella in water has been put in place, with clear responsibilities. In March 2005, the Ministry of Housing, Spatial Planning and the Environment (VROM) published a summary on the prevention and the legislation concerning the control of legionella in water. LD prevention is divided into pro-active and reactive source cleansing. For preventive pro-active cleansing, four laws are in place that apply to different water sources (see summary in Table 1). By law, samples to monitor the effectiveness of the preventive measures must be taken at regular intervals from all drinking water sources. Positive tests are reported to the VROM inspectorate. The local Public Health Service is notified in case of a positive culture with more than 1,000 colony-forming units per litre, so that it can give information to the users of the contaminated water installation and, if possible and applicable, communicate with reported patients.

Because the vast majority of cooling towers in the Netherlands are installed at company buildings, the Ministry of Social Affairs and Employment (SZW) is made responsible for the legionella control in cooling towers, as far as its risk for employees is concerned. It is assumed that this will also protect the general population. Registration of these towers in the Netherlands is not addressed by law.

As for preventive reactive legionella source cleansing, the infectious disease law is in place, stating that every physician must report LD patients to the local PHS within 24 hours of the diagnosis after which source tracing and elimination can take place as described above in the 'Methods' section [28].

\section{Next steps}

Although the Ministry of Social Affairs and Employment is responsible for legionella control in wet cooling towers, their actual supervision, so far, is limited. Registration of these towers is not addressed in the law but in a policy regulation, which is a guideline that describes 'best practice'. In response to the Amsterdam outbreak, the minister of Social Affairs and Employment stated that the responsibility for registration of cooling towers lay with the municipalities, and that voluntary registration was expected to be sufficient.

As for drinking water, it is urgently needed that wet cooling towers are sampled at regular intervals, and that these cooling towers, together with their test results, are registered nationally. Positive cultures should be fingerprinted and the results entered in the national database. This way, prevention will improve because maintenance will be monitored, and matches with patients' cultures can be made as soon as possible.

In 2007, a register of wet cooling towers was still not in place. In 2003, 30 wet cooling towers were registered in Amsterdam as part of a study. During the 2006 outbreak 14 new wet cooling towers were found. Although registration of cooling towers is not officially their task, in the beginning of the summer of 2007, the PHS Amsterdam decided to make a start with an updated list of wet cooling towers. At the end of the summer, 73 of such cooling towers were registered, more than twice as many as in 2003. Possibly, with a larger database that also includes cooling tower test results, more sources of such outbreaks as described in this paper can be found and prevented or eliminated faster in the future.

\section{Acknowledgements}

The authors would like to thank public health nurses of the Public Health Service department of infectious diseases for collecting and documenting all data and Jacob Bruin for sampling potential sources during the outbreak.

\section{References}

1. Burnsed LJ, Hicks LA, Smithee LM, Fields BS, Bradley KK, Pascoe N, et al. A large, travel-associated outbreak of legionellosis among hotel guests: utility of the urine antigen assay in confirming Pontiac fever. Clin Infect Dis. 2007;44(2):222-8.

2. Beyrer K, Lai S, Dreesman J, Lee JV, Joseph C, Harrison T, et al. Legionnaires' disease outbreak associated with a cruise liner, August 2003: epidemiological and microbiological findings. Epidemiol Infect. 2007;135(5):802-10.

3. Darelid J, Bengtsson L, Gästrin B, Hallander H, Löfgren S, Malmvall BE, et al. An outbreak of Legionnaires' disease in a Swedish hospital. Scand J Infect Dis. 1994;26(4):417-25.

4. Bender-Beck L, Mühlenberg W, Lück PC, Ott M, Horbach I, Fehrenbach FJ, Wewalka G, et al. [Genomic DNA fingerprints of Legionella pneumophila serogroup 2 strains as an epidemiologic marker][Article in German] Immun Infekt. 1995;23(4):137-9.

5. Nguyen TM, Llef D, Jarraud S, Rouil L, Campese C, Che D, et al. A communitywide outbreak of legionnaires disease linked to industrial cooling towers how far can contaminated aerosols spread? J Infect Dis. 2006;193(1):102-11.

6. García-Fulgueiras A, Navarro C, Fenoll D, García J, González-Diego P, Jiménez Buñuales T, et al. Legionnaires' disease outbreak in Murcia, Spain. Emerg Infect Dis. 2003;9(8):915-21. 
7. Sabria M, Alvarez J, Dominguez A, Pedrol A, Sauca G, Salleras L, et al. A community outbreak of Legionnaires' disease: evidence of a cooling tower as the source. Clin Microbiol Infect. 2006;12(7):642-7.

8. Rota MC, Pontrelli G, Scaturro M, Bella A, Bellomo AR, Trinito MO, et al. Legionnaires' disease outbreak in Rome, Italy. Epidemiol Infect. 2005;133(5):853-9.

9. Jansà JM, Caylà JA, Ferrer D, Gracia J, Pelaz C, Salvador M, et al. An outbreak of Legionnaires' disease in an inner city district: importance of the first 24 hours in the investigation. Int J Tuberc Lung Dis. 2002;6(9):831-8.

10. Barricarte A, García Cenoz M, Castilla J, Aldaz P. Current legionellosis outbreak with 139 cases in Pamplona, Spain. Euro Surveill. 2006;11(23):pii=2967. Available from: http://www.eurosurveillance.org/ViewArticle.aspx?ArticleId=2967.

11. Sala MR, Arias C, Oliva JM, Pedrol A, Roura P, Domínguez A. Community outbreak of Legionnaires' disease in Vic-Gurb, Spain in October and November 2005. Euro Surveill. 2007;12(3):pij=691. Available from: http://www.eurosurveillance. org/ViewArticle. aspx? ArticleId=691.

12. Formica N, Tallis G, Zwolak B, Camie J, Beers M, Hogg G, Ryan N, Yates M. Legionnaires' disease outbreak: Victoria's largest identified outbreak. Commun Dis Intell. 2000;24(7):199-202.

13. Hugosson $A$, Hjorth $M$, Bernander S, Claesson BE, Johansson A, Larsson $H$, et al. A community outbreak of Legionnaires' disease from an industrial cooling tower: assessment of clinical features and diagnostic procedures. Scand J Infect Dis. 2007;39(3):217-24.

14. Gilmour MW, Bernard K, Tracz DM, Olson AB, Corbett CR, Burdz T, et al. Molecular typing of a Legionella Pneumophila outbreak in Ontario, Canada. J Med Microbiol. 2007;56(Pt 3):336-41.

15. Kirrage D, Reynolds G, Smith GE, Olowokure B; Hereford Legionnaires Outbreak Control Team. Investigation of an outbreak of Legionnaires' disease: Hereford, UK 2003. Respir Med. 2007;101(8):1639-44.

16. Den Boer JW, Yzerman EP, Schellekens J, Lettinga KD, Boshuizen HC, Van Steenbergen JE, et al. A large outbreak of Legionnaires' disease at a flower show, the Netherlands, 1999. Emerg Infect Dis. 2002;8(1):37-43.

17. RIVM, Centrum Infectieziektebestrijding (CIb). [Legionellosis] [in Dutch]. Available from: http://www.rivm.nl/cib/infectieziekten-A-Z/infectieziekten/ legionellose/index.jsp

18. European Surveillance Scheme for Travel Associated Legionnaires' Disease. Available from: http://www.ewgli.org (accessed 9 July 2007)

19. Editorial team, van den Hoek A. Outbreak of legionnaires' disease in Amsterdam, June-July 2006. Euro Surveill. 2006;11(28):pii=2999. Available from: http://www.eurosurveillance.org/ViewArticle.aspx?ArticleId=2999

20. International Society for Infectious Diseases. ProMED Mail. Legionellosis Amsterdam: Alert - request for information. 13 July 2006. Archive Number 20060713.1929. Available from: http://www.promedmail.org/pls/otn/f?p=240 0:1202:2000398761438311::NO::F2400_P1202_CHECK_DISPLAY,F2400_P1202_PUB_ MAIL_ID:X,33558

21. van Steenbergen JE, Slijkerman FA, Speelman P. The first 48 hours of investigation and intervention of an outbreak of legionellosis in the Netherlands. Euro Surveill. 1999;4(11):pii=59. Available from: http://www. eurosurveillance.org/ViewArticle.aspx?ArticleId $=59$.

22. Den Boer JW, Verhoef L, Bencini MA, Bruin JP, Jansen R, Yzerman EP. Outbreak detection and secondary prevention of Legionnaires' disease: a national approach. Int J Hyg Environ Health. 2007;210(1):1-7.

23. Public Health Service Kennemerland. Newsletter June 2006. [Source tracing unit legionella pneumonia: results and future] [in Dutch]

24. Joseph CA, van der Sande M. Unexplained summer increase in nontravel related legionellosis in the UK and Netherlands. Euro Surveill. 2006;11(42):pii=3065. Available from: http://www.eurosurveillance.org/ ViewArticle.aspx?ArticleId $=3065$

25. Karagiannis I, Brandsema P, van der Sande M. Warm, wet weather associated with increased Legionnaires' disease incidence in The Netherlands. Epidemiol Infect. 2008 Jul 17:1-7.

26. Sheldon T. Dutch launch plan to combat legionnaires' disease. BMJ. 1999;318(7196):1437.

27. Health Council of the Netherlands. Controlling Legionnaires' Disease. The Hague: Health Council of the Netherlands; 2003. Available from: http://www. gr.nl/samenvatting.php?ID $=728$

28. Health Care Inspectorate [Inspectie voor de Gezondheidszorg IGZ] Appendix with circular letter 2003-14-IGZ. Available from: http://www.igz. nl/15446/67900/Circulaire_2003-14_meldings1.pdf
This article was published on 18 September 2008.

Citation style for this article: Sonder GJ, van den Hoek JA, Bovée LP, Aanhane FE, Worp J, Du Ry van Beest Holle M, van Steenbergen JE, den Boer JW, Ijzerman EP, Coutinho RA. Changes in prevention and outbreak management of Legionnaires' diseas in the Netherlands between two large outbreaks in 1999 and 2006. Euro Surveill. 2008;13(38):pii=18983. Available online: http://www.eurosurveillance.org/ViewArticle. aspx?ArticleId $=18983$ 